\title{
PENILAIAN KEPUTUSAN INVESTASI SAHAM DALAM PENERAPAN \\ INSENTIF PAJAK PENJUALAN ATAS BARANG MEWAH (PPnBM) \\ BAGI PERUSAHAAN GO PUBLIC DI ERA PANDEMI COVID-19 (STUDI KASUS PADA PERUSAHAAN SEKTOR OTOMOTIF)
}

\author{
Alther Gabriel Liwe ${ }^{1}$, Novi Swandari Budiarso ${ }^{2}$, Winston Pontoh ${ }^{3}$ \\ ${ }^{1}$ Kantor Cabang Manado Timur, Kantor Wilayah V Manado, PT. Pegadaian (Persero) \\ ${ }^{2,3}$ Program Studi Profesi Akuntan, Fakultas Ekonomi dan Bisnis, Universitas Sam Ratulangi, J1. Kampus Bahu, \\ Manado, 95115, Indonesia \\ E-mail: alther.liwe@pegadaian.co.id
}

\begin{abstract}
In the midst of the Covid-19 pandemic, investors need to see and assess the level of risk to determine investment decisions. With various government policies, especially the Sales Tax Incentive on Luxury Goods (PPnBM), we can assess and compare the level of risk and risk before the issuance of this regulation, so that investors can make the best investment decisions in the midst of the Covid-19 pandemic. The stock beta for the automotive sector was still stable when the PPnBM incentive was implemented, as shown by the calculation of the CAPM Capital Asset Pricing Model, which is mostly below 1. The impact of the Covid-19 pandemic is still felt in world investment and tends to improve over time.
\end{abstract}

Keywords: risk and return; CAPM; eficient market hypothesis; stock investment; tax incentive; PPnBM; Covid-19

\section{PENDAHULUAN}

Investasi manjadi salah satu indikator penentu apakah pembangunan ekonomi nasional ke depannya akan terus meningkat atau tidak, dengan pemikiran itu pemerintah mengeluarkan berbagai macam kebijakan untuk meningkatkan investasi agar mendorong perekomian negara dan membantu para investor maupun calon investor aman dalam berivenstasi. Di era pandemi, kinerja portofolio investasi menurun drastis termasuk pasar modal khususnya saham sehingga pemerintah mengeluarkan berbagai macam kebijakan untuk mendorong peningkatan perekonomian. Salah satu kebijakan yang di keluarkan pemerintah yaitu Insentif Pajak yang di mulai sejak tahun 2020 melalui Peraturan Menteri Keuangan Republik Indonesia. Pada tahun 2021, Menteri Keuangan RI Sri Mulyani menerbitkan kebijakan Insentif Pajak untuk mendorong ekonomi pada sektor otomotif, kebijakan tersebut tertuang dalam Peraturan Menteri Keuangan (PMK) Nomor 31/PMK.010/2021 tentang Pajak Penjualan Atas Barang Mewah Atas Penyerahan Barang Kena Pajak Yang Tergolong Mewah Berupa Kendaraan Bermotor Tertentu yang Ditanggung Pemerintah Tahun Anggaran 2021 dan mulai berlaku per tanggal 1 April 2021.

Menurut Pontoh dan Budiarso (2019), setiap bentuk investasi umumnya memiliki risiko dan investasi saham merupakan bentuk investasi yang tidak lepas dari adanya risiko, sehingga masyarakat secara umum dapat memanfaatkan ipteks dalam mengelola portofolio investasinya dengan tujuan untuk melakukan pengelolaan atas tingkat pengembalian dan risiko dari investasi yang dilakukan. Di tengah pandemi Covid-19 investor perlu mengetahui dan menilai tingkat risiko untuk menentukan keputusan investasi, dalam hal ini saham. Adanya berbagai kebijakan pemerintah khusunya Insentif Pajak Penjualan Atas Barang Mewah (PPnBM) maka kita dapat menilai dan membandingkan tingkat pengembalian dan risiko sebelum dan sesudah diterbitkannya peraturan ini, agar investor dapat mengambil keputusan investai terbaik di tengah pandemi Covid-19. Diharapkan kebijakan Insentif Pajak 
meningkatkan investasi pada pasar modal saham dan tarif pajak khusus PPnBM meningkatkan gairah ekonomi sektor otomotif.

\section{TINJAUAN PUSTAKA}

\subsection{Efficient Market Hypothesis (EMH)}

EMH dipopulerkan oleh Fama (1970) dimana bagaimana suatu pasar bereaksi terhadap suatu informasi untuk mencapai harga ekuilibrium yang baru merupakan hal yang penting. Jika pasar bereaksi dengan cepat dan akurat untuk mencapai harga ekuilibrium baru yang sepenuhnya mencerminkan informasi yang tersedia, maka kondisi pasar seperti ini disebut dengan pasar efisien. Efisiensi pasar seperti ini disebut dengan efisiensi pasar secara informasi yaitu bagaimana pasar bereaksi terhadap informasi yang ada.

\subsection{Capital Asset Pricing Model (CAPM)}

CAPM adalah bentuk standar dari general equilibrium relationship bagi return asset yang dikembangkan secara terpisah oleh Sharpe (1964), Lintner (1965), dan Mossin (1966) sehingga model CAPM juga disebut juga dengan model Sharpe-Lintner-Mossin. Menurut Francis (1991), CAPM adalah suatu metode penilaian risiko dan keuntungan aset yang didasarkan atas indeks risiko yang tidak dapat didiversifikasi atau koefisien beta. Menurut Bodie et al. (2009:279), CAPM merupakan model untuk melakukan prediksi atas tingkat pengembalian sebuah investasi yang berisiko.

\subsection{Risiko dan tingkat pengembalian}

Menurut Fahmi (2015:189), risiko dapat diartikan sebagai bentuk keadaan ketidakpastian tentang suatu keadaan yang akan terjadi nantinya dengan keputusan yang diambil berdasarkan berbagai pertimbangan saat ini. Tingkat pengembalian (return) merupakan tingkat pengembalian berupa keuntungan atau kerugian dari investasi yang telah dilakukan oleh investor yang disebabkan oleh kenaikan atau penurunan dari nilai investasi. Tandelilin (2001:47) mendefinisikan pengembalian investasi sebagai salah satu faktor yang memotivasi interaksi investor juga sebagai imbalan atas keberanian investor yang telah menanggung risiko atas investasi yang dilakoninya. Lakonishok dan Shapiro (1986), Bollerslev dan Zhang (2003), Bora dan Adhikary (2015), Aliu et al. (2017), dan Budiarso dan Pontoh (2019) menemukan bahwa risiko memiliki hubungan positif dengan tingkat pengembalian saham sehingga dalam dunia investasi dikenal "high risk, high return" yang berarti bahwa ketika risiko investasi semakin tinggi maka akan semakin tinggi potensi tingkat pengembalian yang akan didapatkan oleh seorang investor. Brigham dan Ehrhardt (2017:259), dan Ross et al. (2018:345) menjelaskan bahwa salah satu indikator risiko adalah risiko pasar (beta saham) dimana jika beta saham lebih besar sama dengan 1 maka hal ini menunjukkan bahwa saham tersebut adalah berisiko dan jika bernilai kurang dari 1 maka hal ini berarti saham tersebut kurang berisiko.

\subsection{Pajak Penjualan Atas Barang Mewah (PPnBM)}

PPnBM yaitu pajak yang dikenakan selain Pajak Pertambahan Nilai (PPN) untuk penjualan barang-barang yang tergolong sebagai barang mewah. PPnBM merupakan jenis pajak yang merupakan satu paket dalam Undang-Undang Pajak Pertambahan Nilai. Kebijakan PPnBM tarif 0\% melalui penerbitan Peraturan Menteri Keuangan nomor 31/PMK.010/2021 tentang Pajak Penjualan atas Barang Mewah atas Penyerahan Barang Kena Pajak yang Tergolong Mewah Berupa Kendaraan Bermotor Tertentu yang Ditanggung Pemerintah Tahun Anggaran 2021 dan mulai diberlakukan pada April 2021.

\section{METODE DAN TEKNIK PENERAPAN IPTEKS}

\subsection{Metode penerapan ipteks}

Metode yang digunakan dalam penerapan ipteks adalah analisis kuantitatif berdasarkan CAPM. Data yang digunakan yaitu data sekunder berupa harga pasar saham dan 
tingkat bunga acuan Bank Indonesia. Objek data yaitu perusahaan sektor otomotif yang terdaftar di Bursa Efek Indonesia (BEI) hingga April 2021. Tabel 1 menyajikan daftar perusahaan terbuka yang bergerak di sektor otomotif.

Tabel 1. Daftar perusahaan sektor otomotif

\begin{tabular}{cll}
\hline No. & \multicolumn{1}{c}{ Kode Emiten } & \multicolumn{1}{c}{ Nama Perusahaan } \\
\hline 1 & ASII & PT Astra International Tbk \\
2 & AUTO & PT Astra Otoparts Tbk \\
3 & BOLT & PT Garuda Metalindo Tbk \\
4 & BRAM & PT Indo Kordsa Tbk \\
5 & GDYR & PT Goodyear Indonesia Tbk \\
6 & GJTL & PT Gajah Tunggal Tbk \\
7 & IMAS & PT Indomobil Sukses Internasional Tbk \\
8 & INDS & PT Indospring Tbk \\
9 & LPIN & PT Multi Prima Sejahtera Tbk \\
10 & PRAS & PT Prima Alloy Steel Universal Tbk \\
11 & SMSM & PT Selamat Sempurna Tbk \\
\hline Sumber: https://www.idx.co.id/data-pasar/data-saham/daftar-saham/
\end{tabular}

\subsection{Teknik penerapan ipteks}

Teknik atas penerapan ipteks CAPM dilakukan dengan langkah-langkah berikut.

1. Menentukan tingkat pengembalian saham sebuah perusahaan dalam periode tertentu atau disimbolkan dengan $\mathrm{R}_{\mathrm{it}}$, dimana $\mathrm{R}$ adalah tingkat pengembalian saham atas harga pasar (return), i adalah perusahaan yang memiliki saham, dan $\mathrm{t}$ adalah periode tingkat pengembalian tersebut.

2. Menentukan tingkat pengembalian pasar saham atau disimbolkan dengan $\mathrm{R}_{\mathrm{mt}}$, dimana $\mathrm{R}$ adalah tingkat pengembalian harga pasar saham gabungan (market return), adalah harga pasar yang diambil berdasarkan indeks yang ditentukan, dan $\mathrm{t}$ adalah periode tingkat pengembalian tersebut.

3. Menentukan tingkat return bebas risiko (risk free) atau disimbolkan dengan $\mathrm{R}_{\mathrm{f}}$, dimana $\mathrm{R}$ adalah suku bunga (return) bebas risiko.

4. Menentukan risiko pasar (market risk) berdasarkan CAPM dengan persamaan berikut.

$$
\mathrm{R}_{\mathrm{it}}-\mathrm{R}_{\mathrm{f}}=\alpha+\beta \mathrm{R}_{\mathrm{mt}}-\mathrm{R}_{\mathrm{f}}+\varepsilon_{\mathrm{it}}
$$

\section{PEMBAHASAN}

\subsection{Hasil analisis}

Tabel 2 menyajikan harga pasar saham setiap perusahaan yang akan digunakan untuk menghitung tingkat pengembalian saham dalam periode tertentu (rate of return) atau $\mathrm{R}_{\mathrm{it}}$.

Tabel 2. Harga pasar saham 30 hari s.d. 06 April 2021

\begin{tabular}{rrrrrrrrrrrr}
\hline TGL & ASII & AUTO & BOLT & BRAM & GDYR & GJTL & IMAS & INDS & LPIN & PRAS & SMSM \\
\hline $22 / 02$ & 5.700 & 1.025 & 745 & 4.800 & 1.400 & 845 & 1.260 & 1.880 & 254 & 145 & 1.285 \\
$23 / 02$ & 5.725 & 1.025 & 700 & 4.800 & 1.750 & 835 & 1.290 & 1.880 & 246 & 145 & 1.275 \\
$24 / 02$ & 5.625 & 1.040 & 740 & 4.750 & 2.180 & 860 & 1.310 & 1.880 & 256 & 142 & 1.280 \\
$25 / 02$ & 5.575 & 1.045 & 720 & 4.900 & 2.720 & 880 & 1.325 & 1.900 & 256 & 149 & 1.295 \\
$26 / 02$ & 5.400 & 1.050 & 690 & 4.710 & 3.030 & 855 & 1.330 & 1.885 & 254 & 155 & 1.305 \\
$01 / 03$ & 5.600 & 1.060 & 705 & 4.730 & 3.030 & 845 & 1.355 & 1.870 & 254 & 150 & 1.320 \\
$02 / 03$ & 5.575 & 1.060 & 700 & 4.830 & 3.050 & 840 & 1.325 & 1.870 & 254 & 158 & 1.325 \\
$03 / 03$ & 5.675 & 1.055 & 820 & 4.800 & 2.840 & 815 & 1.300 & 1.870 & 254 & 160 & 1.365 \\
$04 / 03$ & 5.575 & 1.070 & 1.025 & 4.750 & 2.650 & 815 & 1.220 & 1.885 & 256 & 160 & 1.400 \\
$05 / 03$ & 5.500 & 1.105 & 1.280 & 4.800 & 2.470 & 810 & 1.160 & 1.875 & 256 & 169 & 1.350 \\
$08 / 03$ & 5.550 & 1.140 & 1.195 & 4.800 & 2.300 & 825 & 1.120 & 1.880 & 256 & 158 & 1.305 \\
$09 / 03$ & 5.525 & 1.165 & 1.195 & 4.800 & 2.140 & 875 & 1.190 & 1.885 & 256 & 152 & 1.275 \\
$10 / 03$ & 5.425 & 1.145 & 1.115 & 4.700 & 1.995 & 860 & 1.145 & 1.890 & 254 & 152 & 1.270 \\
\hline
\end{tabular}


Tabel 2. Harga pasar saham 30 hari s.d. 06 April 2021 (lanjutan)

\begin{tabular}{ccrrrrrrrrrr}
\hline TGL & ASII & AUTO & BOLT & BRAM & GDYR & GJTL & IMAS & INDS & LPIN & PRAS & SMSM \\
\hline $12 / 03$ & 5.475 & 1.160 & 1.040 & 4.850 & 1.950 & 850 & 1.175 & 1.870 & 244 & 150 & 1.315 \\
$15 / 03$ & 5.525 & 1.200 & 970 & 4.870 & 1.840 & 880 & 1.240 & 1.875 & 246 & 148 & 1.315 \\
$16 / 03$ & 5.550 & 1.215 & 905 & 4.800 & 1.940 & 955 & 1.250 & 1.870 & 250 & 139 & 1.310 \\
$17 / 03$ & 5.575 & 1.280 & 845 & 4.800 & 1.880 & 910 & 1.220 & 1.870 & 248 & 148 & 1.315 \\
$18 / 03$ & 5.725 & 1.275 & 835 & 4.850 & 1.845 & 920 & 1.235 & 1.870 & 246 & 153 & 1.305 \\
$19 / 03$ & 5.775 & 1.265 & 780 & 4.850 & 1.825 & 915 & 1.205 & 1.880 & 248 & 144 & 1.300 \\
$22 / 03$ & 5.575 & 1.250 & 770 & 4.850 & 1.845 & 915 & 1.195 & 1.875 & 254 & 144 & 1.300 \\
$23 / 03$ & 5.575 & 1.215 & 720 & 4.800 & 1.750 & 885 & 1.220 & 1.885 & 254 & 150 & 1.280 \\
$24 / 03$ & 5.450 & 1.200 & 775 & 4.800 & 1.635 & 860 & 1.185 & 1.870 & 246 & 143 & 1.275 \\
$25 / 03$ & 5.450 & 1.160 & 760 & 4.710 & 1.560 & 890 & 1.175 & 1.870 & 250 & 143 & 1.285 \\
$26 / 03$ & 5.600 & 1.185 & 710 & 4.710 & 1.595 & 890 & 1.200 & 1.865 & 244 & 143 & 1.305 \\
$29 / 03$ & 5.525 & 1.215 & 715 & 4.710 & 1.555 & 895 & 1.185 & 1.875 & 248 & 143 & 1.320 \\
$30 / 03$ & 5.400 & 1.190 & 750 & 4.710 & 1.510 & 895 & 1.125 & 1.860 & 248 & 147 & 1.330 \\
$31 / 03$ & 5.275 & 1.160 & 705 & 4.700 & 1.480 & 880 & 1.080 & 1.870 & 248 & 142 & 1.340 \\
$01 / 04$ & 5.350 & 1.170 & 705 & 4.800 & 1.555 & 880 & 1.070 & 1.825 & 250 & 143 & 1.345 \\
$05 / 04$ & 5.350 & 1.175 & 720 & 4.700 & 1.520 & 895 & 1.060 & 1.870 & 250 & 147 & 1.360 \\
$06 / 04$ & 5.350 & 1.185 & 730 & 4.650 & 1.520 & 905 & 1.065 & 1.865 & 252 & 155 & 1.360 \\
\hline Sumber: https://finance.yahoo.com/lookup & & & & & & & & &
\end{tabular}

Berdasarkan harga pasar saham perusahaan sektor otomotif, maka diperoleh tingkat pengembalian saham $\left(\mathrm{R}_{\mathrm{it}}\right)$ dengan menggunakan rumus:

$$
\mathrm{R}_{\mathrm{it}}=\frac{\mathrm{P}_{1}-\mathrm{P}_{0}}{\mathrm{P}_{0}}
$$

$\mathrm{P}_{1}$ adalah harga pasar saham periode tertentu dan $\mathrm{P}_{0}$ adalah harga pasar saham periode sebelumnya. Tabel 3 menyajikan tingkat pengembalian saham $\left(\mathrm{R}_{\mathrm{it}}\right)$ atas perusahaan sektor otomotif.

Tabel 3. Tingkat pengembalian saham

\begin{tabular}{|c|c|c|c|c|c|c|c|c|c|c|c|}
\hline TGL & ASII & AUTO & BOLT & BRAM & GDYR & GJTL & IMAS & INDS & LPIN & PRAS & SMSM \\
\hline $23 / 02$ & 0,44 & 0,00 & $-6,43$ & 0,00 & 20,00 & $-1,20$ & 2,33 & 0,00 & $-3,25$ & 0,00 & $-0,78$ \\
\hline $24 / 02$ & $-1,78$ & 1,44 & 5,41 & $-1,05$ & 19,72 & 2,91 & 1,53 & 0,00 & 3,91 & $-2,11$ & 0,39 \\
\hline $25 / 02$ & $-0,90$ & 0,48 & $-2,78$ & 3,06 & 19,85 & 2,27 & 1,13 & 1,05 & 0,00 & 4,70 & 1,16 \\
\hline $26 / 02$ & $-3,24$ & 0,48 & $-4,35$ & $-4,03$ & 10,23 & $-2,92$ & 0,38 & $-0,80$ & $-0,79$ & 3,87 & 0,77 \\
\hline $01 / 03$ & 3,57 & 0,94 & 2,13 & 0,42 & 0,00 & $-1,18$ & 1,85 & $-0,80$ & 0,00 & $-3,33$ & 1,14 \\
\hline $02 / 03$ & $-0,45$ & 0,00 & $-0,71$ & 2,07 & 0,66 & $-0,60$ & $-2,26$ & 0,00 & 0,00 & 5,06 & 0,38 \\
\hline $03 / 03$ & 1,76 & $-0,47$ & 14,63 & $-0,63$ & $-7,39$ & $-3,07$ & $-1,92$ & 0,00 & 0,00 & 1,25 & 2,93 \\
\hline 04/03 & $-1,79$ & 1,40 & 20,00 & $-1,05$ & $-7,17$ & 0,00 & $-6,56$ & 0,80 & 0,78 & 0,00 & 2,50 \\
\hline $05 / 03$ & $-1,36$ & 3,17 & 19,92 & 1,04 & $-7,29$ & $-0,62$ & $-5,17$ & $-0,53$ & 0,00 & 5,33 & $-3,70$ \\
\hline 08/03 & 0,90 & 3,07 & $-7,11$ & 0,00 & $-7,39$ & 1,82 & $-3,57$ & 0,27 & 0,00 & $-6,96$ & $-3,45$ \\
\hline $09 / 03$ & $-0,45$ & 2,15 & 0,00 & 0,00 & $-7,48$ & 5,71 & 5,88 & 0,27 & 0,00 & $-3,95$ & $-2,35$ \\
\hline $10 / 03$ & $-1,84$ & $-1,75$ & $-7,17$ & $-2,13$ & $-7,27$ & $-1,74$ & $-3,93$ & 0,26 & $-0,79$ & 0,00 & $-0,39$ \\
\hline $12 / 03$ & 0,91 & 1,29 & $-7,21$ & 3,09 & $-2,31$ & $-1,18$ & 2,55 & $-1,07$ & $-4,10$ & $-1,33$ & 3,42 \\
\hline $15 / 03$ & 0,90 & 3,33 & $-7,22$ & 0,41 & $-5,98$ & 3,41 & 5,24 & 0,27 & 0,81 & $-1,35$ & 0,00 \\
\hline
\end{tabular}


Tabel 3. Tingkat pengembalian saham (lanjutan)

\begin{tabular}{crrrrrrrrrrr}
\hline TGL & ASII & AUTO & BOLT & BRAM & GDYR & GJTL & IMAS & INDS & LPIN & PRAS & SMSM \\
\hline $16 / 03$ & 0,45 & 5,08 & $-7,10$ & 0,00 & $-3,19$ & $-4,95$ & $-2,46$ & 0,00 & $-0,81$ & 6,08 & 0,38 \\
$17 / 03$ & 2,62 & $-0,39$ & $-1,20$ & 1,03 & $-1,90$ & 1,09 & 1,21 & 0,00 & $-0,81$ & 3,27 & $-0,77$ \\
$18 / 03$ & 0,87 & $-0,79$ & $-7,05$ & 0,00 & $-1,10$ & $-0,55$ & $-2,49$ & 0,53 & 0,81 & $-6,25$ & $-0,38$ \\
$19 / 03$ & $-3,59$ & $-1,20$ & $-1,30$ & 0,00 & 1,08 & 0,00 & $-0,84$ & $-0,27$ & 2,36 & 0,00 & 0,00 \\
$22 / 03$ & 0,00 & $-2,88$ & $-6,94$ & $-1,04$ & $-5,43$ & $-3,39$ & 2,05 & 0,53 & 0,00 & 4,00 & $-1,56$ \\
$23 / 03$ & $-2,29$ & $-1,25$ & 7,10 & 0,00 & $-7,03$ & $-2,91$ & $-2,95$ & $-0,80$ & $-3,25$ & $-4,90$ & $-0,39$ \\
$24 / 03$ & 0,00 & $-3,45$ & $-1,97$ & $-1,91$ & $-4,81$ & 3,37 & $-0,85$ & 0,00 & 1,60 & 0,00 & 0,78 \\
$25 / 03$ & 2,68 & 2,11 & $-7,04$ & 0,00 & 2,19 & 0,00 & 2,08 & $-0,27$ & $-2,46$ & 0,00 & 1,53 \\
$26 / 03$ & $-1,36$ & 2,47 & 0,70 & 0,00 & $-2,57$ & 0,56 & $-1,27$ & 0,53 & 1,61 & 0,00 & 1,14 \\
$29 / 03$ & $-2,31$ & $-2,10$ & 4,67 & 0,00 & $-2,98$ & 0,00 & $-5,33$ & $-0,81$ & 0,00 & 2,72 & 0,75 \\
$30 / 03$ & $-2,37$ & $-2,59$ & $-6,38$ & $-0,21$ & $-2,03$ & $-1,70$ & $-4,17$ & 0,53 & 0,00 & $-3,52$ & 0,75 \\
$31 / 03$ & 1,40 & 0,85 & 0,00 & 2,08 & 4,82 & 0,00 & $-0,93$ & $-2,47$ & 0,80 & 0,70 & 0,37 \\
$01 / 04$ & 0,00 & 0,43 & 2,08 & $-2,13$ & $-2,30$ & 1,68 & $-0,94$ & 2,41 & 0,00 & 2,72 & 1,10 \\
$05 / 04$ & 0,00 & 0,84 & 1,37 & $-1,08$ & 0,00 & 1,10 & 0,47 & $-0,27$ & 0,79 & 5,16 & 0,00 \\
$06 / 04$ & 0,45 & 5,08 & $-7,10$ & 0,00 & $-3,19$ & $-4,95$ & $-2,46$ & 0,00 & $-0,81$ & 6,08 & 0,38 \\
\hline Sumber: Data olahan, 2021
\end{tabular}

Tabel 4 menyajikan harga pasar saham gabungan yang digunakan untuk menentukan tingkat pengembalian saham gabungan (rate of market return) atau $\mathrm{R}_{\mathrm{mt}}$ menggunakan rumus yang sama saat menentukan tingkat pengembalian saham (rate of return) atau $\mathrm{R}_{\mathrm{it}}$.

Tabel 4. Harga pasar dan tingkat pengembalian saham gabungan 30 hari s.d. 06 April 2021

\begin{tabular}{|c|c|c|}
\hline Tgl & Harga pasar saham gabungan* & Tingkat pengembalian saham gabungan** \\
\hline $22 / 02$ & 6.255 & \\
\hline $23 / 02$ & 6.273 & 0,28 \\
\hline $24 / 02$ & 6.251 & $-0,35$ \\
\hline $25 / 02$ & 6.290 & 0,61 \\
\hline $26 / 02$ & 6.242 & $-0,77$ \\
\hline $01 / 03$ & 6.339 & 1,53 \\
\hline $02 / 03$ & 6.359 & 0,33 \\
\hline $03 / 03$ & 6.377 & 0,28 \\
\hline 04/03 & 6.291 & $-1,37$ \\
\hline $05 / 03$ & 6.259 & $-0,51$ \\
\hline 08/03 & 6.248 & $-0,16$ \\
\hline $09 / 03$ & 6.200 & $-0,79$ \\
\hline $10 / 03$ & 6.265 & 1,04 \\
\hline $12 / 03$ & 6.358 & 1,47 \\
\hline $15 / 03$ & 6.324 & $-0,54$ \\
\hline $16 / 03$ & 6.310 & $-0,23$ \\
\hline $17 / 03$ & 6.277 & $-0,52$ \\
\hline $18 / 03$ & 6.348 & 1,11 \\
\hline $19 / 03$ & 6.356 & 0,13 \\
\hline $22 / 03$ & 6.301 & $-0,87$ \\
\hline $23 / 03$ & 6.253 & $-0,77$ \\
\hline $24 / 03$ & 6.156 & $-1,57$ \\
\hline $25 / 03$ & 6.123 & $-0,54$ \\
\hline $26 / 03$ & 6.196 & 1,17 \\
\hline $29 / 03$ & 6.167 & $-0,47$ \\
\hline $30 / 03$ & 6.071 & $-1,57$ \\
\hline $31 / 03$ & 5.986 & $-1,44$ \\
\hline $01 / 04$ & 6.011 & 0,43 \\
\hline $05 / 04$ & 5.970 & $-0,69$ \\
\hline 06/04 & 6.003 & 0,54 \\
\hline
\end{tabular}

*Sumber dari https://finance.yahoo.com/quote/\%5EJKSE/history?p=\%5EJKSE,

**Sumber dari data olahan, 2021 
Tabel 5 menyajikan hasil penghitungan kelebihan atas tingkat pengembalian saham (excess return) yang merupakan selisih antara tingkat pengembalian saham dengan tingkat pengembalian investasi bebas risiko $\left(\mathrm{R}_{\mathrm{it}}-\mathrm{R}_{\mathrm{f}}\right)$ dan tingkat pengembalian saham gabungan yang merupakan selisih antara tingkat pengembalian saham gabungan dengan tingkat pengembalian investasi bebas risiko $\left(\mathrm{R}_{\mathrm{mt}}-\mathrm{R}_{\mathrm{f}}\right)$ dimana $\mathrm{R}_{\mathrm{f}}$ didasarkan pada tingkat bunga acuan Bank Indonesia (BI 7-day repo rate) untuk bulan Februari dan Maret atau masing-masing sebesar 0.035 (https://www.bi.go.id/id/statistik/indikator/bi-7day-rr.aspx)

Tabel 5. Kelebihan atas tingkat pengembalian saham dan tingkat pengembalian saham gabungan

\begin{tabular}{|c|c|c|c|c|c|c|c|c|c|c|c|c|}
\hline \multirow{2}{*}{ TGL } & \multicolumn{11}{|c|}{$\mathbf{R}_{\mathrm{it}}-\mathbf{R}_{\mathbf{f}}$} & \multirow{2}{*}{$\mathbf{R}_{\mathrm{mt}}-\mathbf{R}_{\mathrm{f}}$} \\
\hline & ASII & AUTO & BOLT & BRAM & GDYR & GJTL & IMAS & INDS & LPIN & PRAS & SMSM & \\
\hline $23 / 02$ & 0,09 & $-0,35$ & $-6,78$ & $-0,35$ & 19,65 & $-1,55$ & 1,98 & $-0,35$ & $-3,6$ & $-0,35$ & $-1,13$ & $-0,07$ \\
\hline $24 / 02$ & $-2,13$ & 1,09 & 5,06 & $-1,4$ & 19,37 & 2,56 & 1,18 & $-0,35$ & 3,56 & $-2,46$ & 0,04 & $-0,7$ \\
\hline $25 / 02$ & $-1,25$ & 0,13 & $-3,13$ & 2,71 & 19,5 & 1,92 & 0,78 & 0,7 & $-0,35$ & 4,35 & 0,81 & 0,26 \\
\hline $26 / 02$ & $-3,59$ & 0,13 & $-4,7$ & $-4,38$ & 9,88 & $-3,27$ & 0,03 & $-1,15$ & $-1,14$ & 3,52 & 0,42 & $-1,12$ \\
\hline 01/03 & 3,22 & 0,59 & 1,78 & 0,07 & $-0,35$ & $-1,53$ & 1,5 & $-1,15$ & $-0,35$ & $-3,68$ & 0,79 & 1,18 \\
\hline $02 / 03$ & $-0,8$ & $-0,35$ & $-1,06$ & 1,72 & 0,31 & $-0,95$ & $-2,61$ & $-0,35$ & $-0,35$ & 4,71 & 0,03 & $-0,02$ \\
\hline 03/03 & 1,41 & $-0,82$ & 14,28 & $-0,98$ & $-7,74$ & $-3,42$ & $-2,27$ & $-0,35$ & $-0,35$ & 0,9 & 2,58 & $-0,07$ \\
\hline $04 / 03$ & $-2,14$ & 1,05 & 19,65 & $-1,4$ & $-7,52$ & $-0,35$ & $-6,91$ & 0,45 & 0,43 & $-0,35$ & 2,15 & $-1,72$ \\
\hline $05 / 03$ & $-1,71$ & 2,82 & 19,57 & 0,69 & $-7,64$ & $-0,97$ & $-5,52$ & $-0,88$ & $-0,35$ & 4,98 & $-4,05$ & $-0,86$ \\
\hline 08/03 & 0,55 & 2,72 & $-7,46$ & $-0,35$ & $-7,74$ & 1,47 & $-3,92$ & $-0,08$ & $-0,35$ & $-7,31$ & $-3,8$ & $-0,51$ \\
\hline 09/03 & $-0,8$ & 1,8 & $-0,35$ & $-0,35$ & $-7,83$ & 5,36 & 5,53 & $-0,08$ & $-0,35$ & $-4,3$ & $-2,7$ & $-1,14$ \\
\hline $10 / 03$ & $-2,19$ & $-2,1$ & $-7,52$ & $-2,48$ & $-7,62$ & $-2,09$ & $-4,28$ & $-0,09$ & $-1,14$ & $-0,35$ & $-0,74$ & 0,69 \\
\hline $12 / 03$ & 0,56 & 0,94 & $-7,56$ & 2,74 & $-2,66$ & $-1,53$ & 2,2 & $-1,42$ & $-4,45$ & $-1,68$ & 3,07 & 1,12 \\
\hline $15 / 03$ & 0,55 & 2,98 & $-7,57$ & 0,06 & $-6,33$ & 3,06 & 4,89 & $-0,08$ & 0,46 & $-1,7$ & $-0,35$ & $-0,89$ \\
\hline $16 / 03$ & 0,1 & 4,73 & $-7,45$ & $-0,35$ & $-3,54$ & $-5,3$ & $-2,81$ & $-0,35$ & $-1,16$ & 5,73 & 0,03 & $-0,58$ \\
\hline $17 / 03$ & 2,27 & $-0,74$ & $-1,55$ & 0,68 & $-2,25$ & 0,74 & 0,86 & $-0,35$ & $-1,16$ & 2,92 & $-1,12$ & $-0,87$ \\
\hline $18 / 03$ & 0,52 & $-1,14$ & $-7,4$ & $-0,35$ & $-1,45$ & $-0,9$ & $-2,84$ & 0,18 & 0,46 & $-6,6$ & $-0,73$ & 0,76 \\
\hline $19 / 03$ & $-3,94$ & $-1,55$ & $-1,65$ & $-0,35$ & 0,73 & $-0,35$ & $-1,19$ & $-0,62$ & 2,01 & $-0,35$ & $-0,35$ & $-0,22$ \\
\hline $22 / 03$ & $-0,35$ & $-3,23$ & $-7,29$ & $-1,39$ & $-5,78$ & $-3,74$ & 1,7 & 0,18 & $-0,35$ & 3,65 & $-1,91$ & $-1,22$ \\
\hline $23 / 03$ & $-2,64$ & $-1,6$ & 6,75 & $-0,35$ & $-7,38$ & $-3,26$ & $-3,3$ & $-1,15$ & $-3,6$ & $-5,25$ & $-0,74$ & $-1,12$ \\
\hline $24 / 03$ & $-0,35$ & $-3,8$ & $-2,32$ & $-2,26$ & $-5,16$ & 3,02 & $-1,2$ & $-0,35$ & 1,25 & $-0,35$ & 0,43 & $-1,92$ \\
\hline $25 / 03$ & 2,33 & 1,76 & $-7,39$ & $-0,35$ & 1,84 & $-0,35$ & 1,73 & $-0,62$ & $-2,81$ & $-0,35$ & 1,18 & $-0,89$ \\
\hline $26 / 03$ & $-1,71$ & 2,12 & 0,35 & $-0,35$ & $-2,92$ & 0,21 & $-1,62$ & 0,18 & 1,26 & $-0,35$ & 0,79 & 0,82 \\
\hline $29 / 03$ & $-2,66$ & $-2,45$ & 4,32 & $-0,35$ & $-3,33$ & $-0,35$ & $-5,68$ & $-1,16$ & $-0,35$ & 2,37 & 0,4 & $-0,82$ \\
\hline $30 / 03$ & $-2,72$ & $-2,94$ & $-6,73$ & $-0,56$ & $-2,38$ & $-2,05$ & $-4,52$ & 0,18 & $-0,35$ & $-3,87$ & 0,4 & $-1,92$ \\
\hline $31 / 03$ & 1,05 & 0,5 & $-0,35$ & 1,73 & 4,47 & $-0,35$ & $-1,28$ & $-2,82$ & 0,45 & 0,35 & 0,02 & $-1,79$ \\
\hline 01/04 & $-0,35$ & 0,08 & 1,73 & $-2,48$ & $-2,65$ & 1,33 & $-1,29$ & 2,06 & $-0,35$ & 2,37 & 0,75 & 0,08 \\
\hline 05/04 & $-0,35$ & 0,49 & 1,02 & $-1,43$ & $-0,35$ & 0,75 & 0,12 & $-0,62$ & 0,44 & 4,81 & $-0,35$ & $-1,04$ \\
\hline 06/04 & 0,1 & 4,73 & $-7,45$ & $-0,35$ & $-3,54$ & $-5,3$ & $-2,81$ & $-0,35$ & $-1,16$ & 5,73 & 0,03 & 0,19 \\
\hline
\end{tabular}

Sumber dari data olahan, 2021

Berdasarkan persamaan CAPM maka penghitungan beta $(\beta)$ saham dapat dilakukan dengan melakukan analisis regresi. Tabel 6 menyajikan beta saham atas perusahaan terbuka yang bergerak di sektor otomotif dengan menggunakan fungsi SLOPE pada Ms. Excel.

Tabel 6. Beta Saham

\begin{tabular}{ccc}
\hline Saham & Beta Saham & Keterangan \\
\hline ASII & 0,478197454 & Kurang Berisiko \\
AUTO & 0,482412993 & Kurang Berisiko \\
BOLT & $-1,833917165$ & Berisiko \\
BRAM & 0,439225501 & Kurang Berisiko \\
GDYR & 0,973113093 & Kurang Berisiko \\
GJTL & $-0,496978272$ & Kurang Berisiko \\
IMAS & 0,357700629 & Kurang Berisiko \\
INDS & 0,14491097 & Kurang Berisiko \\
LPIN & $-0,346189298$ & Kurang Berisiko \\
PRAS & $-0,23697656$ & Kurang Berisiko \\
SMSM & 0,3737872 & Kurang Berisiko
\end{tabular}




\subsection{Pembahasan}

Tabel 6 menunjukkan bahwa BOLT memiliki nilai beta saham sebesar negatif 1 maka terindikasi bahwa saham tersebut berisiko jika diinvestasikan, sedangkan saham lainnya ASSI, AUTO, BRAM, GDYR, GJTL, IMAS, INDS, LPIN, PRAS, dan SMSM terindikasi kurang berisiko. Harga saham sektor otomotif terjadi peningkatan pada bulan Maret sampai dengan April dibandingkan Februari adalah berbanding lurus dengan penerapan insentif PPnBM, sedangkan perhitungan penilaian risiko investasi menunjukan pada bulan Maret dan awal April 2021 harga saham sektor otomotif cenderung stabil.

Berdasarkan hasil analisis, saham BOLT dengan nilai beta saham sebesar negatif 1 (satu) memerlukan kehati-hatian dan pertimbangan khusus bagi para investor. Ross et al. (2018:341) menjelaskan bahwa saham dengan beta negatif cenderung berfungsi sebagai lindung nilai yang dapat memberikan manfaat untuk mengurangi risiko portfolio dan sekaligus dapat memberikan keuntungan saat pasar memiliki kinerja yang kurang optimal. Cloninger et al. (2004) membuktikan bahwa beta negatif memiliki fungsi dan makna yang sama seperti halnya beta positif.

\section{KESIMPULAN DAN SARAN}

\subsection{Kesimpulan}

Beta saham untuk perusahaan sektor otomotif masih stabil saat penerapan insentif PPnBM, yang ditunjukan dengan hasil perhitungan CAPM yang sebangian besar masih di bawah 1 artinya tingkat risiko masih rendah. Penerapan kebijakan insentif PPnBM memberi harapan perbaikan ekonomi khusunya sektor otomotif. Dampak pandemi Covid-19 masih dirasakan dalam dunia investasi dan cenderung membaik dari waktu ke waktu.

\subsection{Saran}

Kajian ini menyarankan untuk menambah data yang lebih banyak bagi kajian-kajian berikutnya karena penerapan insentif PPnBM masih tergolong kebijakan baru dan pengaruhnya belum dirasakan signifikan dalam investasi di pasar modal khususnya saham. Investor lebih lagi melihat dampak positif dalam penerapan insentif PPnBM sehingga dapat mempertimbangkan investasi saham di sektor otomotif yang cenderung kurang berisiko dan memiliki prospek tingkat pengembalian positif.

\section{DAFTAR PUSTAKA}

Aliu, F., Pavelkova, D., \& Dehning, B. (2017). Portfolio risk-return analysis: The case of the automotive industry in the Czech Republic. Journal of International Studies, 10(4), 72-83. https://doi.org/10.14254/2071-8330.2017/10-4/5

Bodie, Z., Kane, A., \& Marcus, A. J. (2009). Investments, $8^{\text {th }}$ Edition. New York: McGrawHill, Irwin.

Bollerslev, T., \& Zhang, B. Y. B. (2003). Measuring and modeling systematic risk in factor pricing models using high-frequency data. Journal of Empirical Finance, 10, 533558. https://doi.org/10.1016/S0927-5398(03)00004-5

Bora, B., \& Adhikary, A. (2015). Risk and return relationship: An empirical study of BSE Sensex companies in India. Universal Journal of Accounting and Finance, 3(2), 4551. https://doi.org/10.13189/ujaf.2015.030203

Brigham, E. F., \& Ehrhardt, M. C. (2017). Financial management: Theory and practice, $15^{\text {th }}$ Edition. United States: Cengage Learning.

Budiarso, N., \& Pontoh, W. (2019). Does maturity signals high risk and high return?. Indonesia Accounting Journal, 1(1), 1-5. https://doi.org/10.32400/iaj.25404 
Cloninger, D. O., Waller, E. R., Bendeck, Y., \& Revere, L. (2004). Returns on negative beta securities: Implications for the empirical SML. Applied Financial Economics, 14(6), 397-402. https://doi.org/10.1080/09603100410001673621

Fahmi, I. (2015). Analisis laporan keuangan. Bandung: Alfabeta.

Fama, E. (1970). Efficient capital markets: A review of theory and empirical work. The Journal of Finance, 25(2), 383-417. https://doi.org/10.2307/2325486

Francis, J. C. (1991). Investments: Analysis and management. United States: McGraw-Hill.

Lakonishok, J., \& Shapiro, A. C. (1986). Systematic risk, total risk and size as determinants of stock market returns. Journal of Banking and Finance, 10(1), 115-132. https://doi.org/10.1016/0378-4266(86)90023-3

Lintner, J. (1965). The valuation of risk assets and the selection of risky investments in stock portfolios and capital budgets. The Review of Economics and Statistics, 47(1), 13-37. https://doi.org/10.2307/1924119

Mossin, J. (1966). Equilibrium in a capital asset market. Econometrica, 34(4), 768-783. https://doi.org/10.2307/1910098

Pontoh, W., \& Budiarso, N. (2019). Ipteks penghitungan risiko pasar dalam keputusan investasi. Jurnal Ipteks Akuntansi Bagi Masyarakat, 3(1), 1-8. https://doi.org/10.32400/jiam.3.1.2019.23302

Ross, S. A., Westerfield, R. W., Jaffe, J. F., \& Jordan, B. D. (2018). Corporate finance: Core principles $\&$ applications, $5^{\text {th }}$ Edition. United States: McGraw-Hill Education.

Sharpe, W. F. (1964). Capital asset prices: A theory of market equilibrium under conditions of risk. The Journal of Finance, 19(3), 425-442. https://doi.org/10.2307/2977928

Tandelilin, E. (2001). Analisis investasi dan manajemen risiko, Edisi Pertama. Yogyakarta: BPFE. 